DOI: https://doi.org/10.24127/ajpm.v10i4.4260

\title{
ANALISIS KEMAMPUAN BERPIKIR TINGKAT TINGGI MENGGUNAKAN INSTRUMEN HOTS BERBASIS TWO TIER DIAGNOSTIC TEST
}

\author{
Sundari Sundari $^{1}$, Muhammad Syahrul Kahar ${ }^{2^{*}}$, Evitari Galu Erwinda ${ }^{3}$ \\ ${ }^{1,2,3}$ Universitas Muhammadiyah Sorong, Sorong, Indonesia \\ ${ }^{*}$ Corresponding author. \\ E-mail: $\quad$ ndarisundari212@ gmail.com $^{1)}$ \\ syahrulkahar@um-sorong.ac.id ${ }^{2 *}$ \\ evitariwinda@gmail.com $^{3)}$
}

Received 29 September 2021; Received in revised form 04 December 2021; Accepted 28 December 2021

\begin{abstract}
Abstrak
Kemampuan berpikir tingkat tinggi mahasiswa cenderung rendah, sehingga berdampak pada kemampuan dalam menerjemahkan substansi pembelajaran yang diberikan. Tujuan dalam penelitian ini untuk mengetahui kemampuan berpikir tingkat tinggi mahasiswa menggunakan instrumen soal Higher Order Thinking Skills (HOTS) berbasis Two Tier Diagnostic Test. Adapun Pendekatan yang dilakukan menggunakan pendekatan kuantitatif dengan Teknik pengumpulan data meliputi instrumen tes. Tahapan analisis data mencakup analisis skor tes, uji normalitas, uji homogenitas, dan uji hipotesis. Hasil yang diperoleh dalam penelitian ini pada uji normalitas memperoleh taraf signifikansi 0,086 sehingga dinyatakan berdistribusi normal dan uji homogenitas dengan taraf signifikansi 0,566 sehingga data dinyatakan homogen. Selanjutnya pada uji regresi linier sederhana diperoleh nilai $t_{\text {hitung }}-1,054$ dengan taraf signifikansi 0,303>0,05. Berdasarkan hasil tersebut dapat di jelaskan bahwa penggunaan instrumen HOTS belum mampu mendorong mahasiswa untuk menelaah informasi yang didapatkan, hal ini terlihat pada rata-rata hasil uji anova menjelaskan bahwa tingkat intrepretasi mahasiswa masih rendah dalam menerjemahkan soal yang diberikan. Oleh karena itu, diperlukan adanya integrasikan pembelajaran yang berkelanjutan.
\end{abstract}

Kata kunci: HOTS; instrumen; two tier diagnostic test.

\begin{abstract}
Students' high-level thinking skills tend to be low, thus impacting the ability to translate the substance of learning provided. The purpose of this study was to find out the high-level thinking skills of students using higher order thinking skills (HOTS) based on the Two Tier Diagnostic Test. The approach taken using a quantitative approach with data collection techniques includes test instruments. The data analysis stages include test score analysis, normality test, homogeneity test, and hypothesis test. The results obtained in this study on the normality test obtained a significance level of 0.086 so that it is declared normal distribution and test homogeneity with a significance level of 0.566 so that the data is declared homogeneous. Furthermore, in the simple linear regression test obtained a value of -1.054 with a significance level of 0.303>0.05. Based on these results, it can be explained that the use of HOTS instruments has not been able to encourage students to review the information obtained, this is seen in the average results of the anova test explaining that the level of student interpretation is still low in translating the given problem. Therefore, there is a need for continuous integration of learning.
\end{abstract}

Keywords: HOTS; instrument; two tier diagnostic test. 
DOI: https://doi.org/10.24127/ajpm.v10i4.4260

\section{PENDAHULUAN}

Pembelajaran di era globalisasi dalam hal ini penggunaan media saat ini, memudahkan mahasiswa dan dosen dalam mencari sumber materi. Menurut (Dewanti, 2011) penggunaan media pembelajaran dapat dikembangkan dengan memanfaatkan kemampuan berpikir, seperti berpikir kritis dan kreatif maka dari itu sangat penting diintegrasikan dalam kehidupan keseharian dengan tetap memperhatikan perkembangan IPTEKS. Menurut (Mahmuzah, 2015) kemampuan berpikir kritis adalah sesuatu bagian yang sangat perlu diperhatikan dan dimiliki oleh mahasiswa dalam proses pembelajaran.

Selaras dengan (Facione, 2011) \& (Kurniasih, 2012) yang mengatakan proses integrasi kemampuan berpikir kritis dan berpikir tingkat tinggi terhadap pemahaman dapat diuraikan ke dalam bagian-bagian mencakup menganalisis, mengintrepretasi dan memaparkan sebuah bukti dari sebuah konsep. Menurut (Heong et al., 2011) \& (Nuryanti et al., 2018) menjelaskan bahwa Higher Order Thinking Skills (HOTS) adalah proses menelaah kemampuan berpikir pada strata yang lebih tinggi ketimbang hanya sekedar menghafal atau mendeskripsikan informasi pada mahasiswa lainnya.

Berdasarkan pemantauan dilapangan menampakkan bahwa ratarata mahasiswa masih kurang memahami secara komprehensif materi yang diberikan oleh dosen dikarenakan mahasiswa kurang dilatih dalam menerjemahkan soal yang diberikan. Disatu sisi mahasiswa juga belum terbiasa dalam mengerjakan soal-soal yang bersifat analisis lanjutan yang merangsang mahasiswa untuk berpikir tingkat tinggi. Maka dari itu perlu adanya kolaborasi pembelajaran yang menggabungkan pola pembelajaran.
Menurut (Rohmah \& Handhika, 2018) dan (Suwarto, 2013) dalam menggunakan instrumen tes diagnostik dengan format two tier test digunakan untuk menemukan miskonsepsi tahap awal dan mengindentifikasi hambatanhambatan yang diperoleh mahasiswa. Selain itu, menurut (Mukhlisa et al., 2020) Two Tier Diagnostic merupakan suatu bentuk tes diagnostik yang berlevel, dimana level 1 menjelaskan tantang konsep yang dipertanyakan dalam pengujian, di level yang kedua menguraikan tentang alasan dari sebuah jawaban yang ada sebelumnya.

Berdasarkan hasil penelitian

Saraswati \& Agustika, (2020) menunjukkan bahwa hasil analisis dalam menelaah kemampuan berpikir HOTS berada pada kategori rendah dalam menemukan solusi pada tingkatan soal kognitif mahasiswa (C6) dan cenderung mengalami kesulitan saat membuat/membentuk kalimat matematika. Sepadan dengan analisis yang dilaksanakan oleh (Ramadhan et al., 2018) mengemukakan bahwa perlu tahapan dalam merancang sebuah soal meliputi tahap analisis (C4), evaluasi (C5), kreasi (C6) dalam mendorong Higher Order Thinking Skills (HOTS) mahasiswa.

Oleh karenanya, dapat dikatakan bahwa penerapan instrumen Two tier diagnostic test mampu mendorong mahasiswa dalam memahami materi secara komprehensif dan tersruktur. Namun dalam mempermudah proses integrasinya, maka perlu adanya salah satu kebaruan melalui pendekatan elaborasi yang mengintegrasikan instrumen Two Tier Diagnostic Test dengan Higher Order Thinking Skills (HOTS) yang diharapkan mampu lebih memperjelas dan mempertajam kemampuan mahasiswa dalam menerima, mengolah dan meng- 
intrepretasi data yang didapatkannya. Maka dari itu, penelitian ini bertujuan untuk mengetahui kemampuan berpikir tingkat tinggi mahasiswa menggunakan instrumen Higher Order Thinking Skills (HOTS) berbasis Two Tier Diagnostic Test.

\section{METODE PENELITIAN}

Metode dalam penelitian ini menggunakan pendekatan kuantitatif. Adapun rancangan dalam penelitian ini meliputi (1) jenis penelitian, (2) metode penelitian, (3) populasi dan sampel, (4) teknik pengumpulan data, dan (5) Teknik analisis data mencakup uji validitas, uji homogenitas dan uji hipotesis. Selanjutnya pengambilan sampel dalam penelitian menggunakan teknik Simple Random Sampling. Adapun alasan Pemilihan ini teknik ini dikarenakan untuk mengurangi potensi bias dalam pemilihan kelompok atau kelas sebagai sampel sehingga diharapkan mampu merepresentasikan sampel. Subjek dalam penelitian yaitu mahasiswa pada semester II, IV dan VI Pendidikan Matematika yang berjumlah 24 mahasiswa. Teknik pengumpulan data yang digunakan meliputi Instrumen Higher Order Thinking Skills berbasis Two Tier Diagnostic Test. Adapun Teknik analisis data menggunakan uji validasi terhadap instrumen, uji Normalitas, Uji homogenitas dan Uji hipotesis menggunakan uji regresi.

Selanjutnya skor tes two tier diagnostic test dianalisis dengan menerapkan petunjuk penskoran dari Graded Response Models (GRM) seperti pada Tabel 1 menurut (Wardani et al., 2015). Skor yang diperoleh kemudian diolah menggunakan spss 25 dan diuraikan ke dalam 5 kategori sebagaimana pada Tabel 2.

Tabel 1. Petunjuk Penskoran Instrumen HOTS berbasis Two Tier

\begin{tabular}{ccc}
\hline \multicolumn{2}{c}{$\begin{array}{c}\text { Respon Jawaban } \\
\text { Mahasiswa }\end{array}$} & Skor \\
\cline { 1 - 2 } First-tier & Second-tier & \\
\hline Benar & Benar & 3 \\
Benar & Salah & 2 \\
Salah & Benar & 1 \\
Salah/Tidak & Salah/Tidak & 0 \\
Menjawab & Menjawab & \\
\hline
\end{tabular}

Tabel 2. Interval Penilaian Higher Order Thinking Skills berbasis Two Tier Diagnostic Test

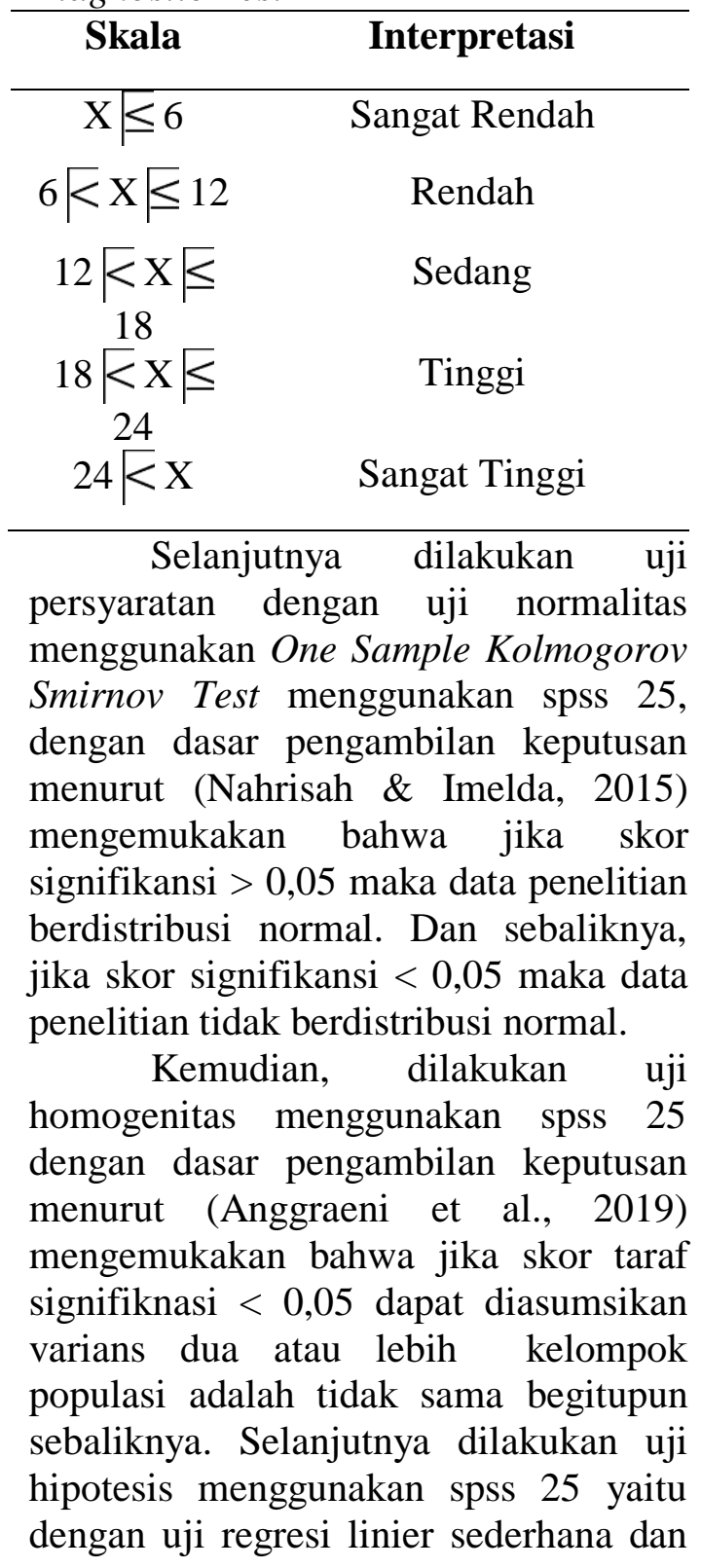


uji one way ANOVA. Untuk uji regresi linier sederhana dasar pengambilan keputusan yang digunakan dengan melihat nilai signifikansi yaitu jika nilai signifikansi < dari probabilitas 0,05 maka $\mathrm{H}_{0}$ ditolak dan $\mathrm{H}_{1}$ diterima. Dan sebaliknya, jika nilai signifikansi $>$ dari probabilitas 0,05 maka $\mathrm{H}_{0}$ diterima dan $\mathrm{H}_{1}$ ditolak. Kemudian untuk uji anova digunakan untuk melihat rata-rata nilai hasil pengerjaan instrument HOTS menggunakan spss 25.

\section{HASIL DAN PEMBAHASAN}

Dalam pelaksanaan dilapangan menunjukkan bahwa terdapat berbagai hasil-hasil yang didapatkan dalam proses menganalisis data, dimana pada instrumen yang ditelah dirancang pada dasarnya mampu memetakan dan mengintrepretasikan pemahaman mahasiswa terhadap sebuah persoalan yang telah diberikan. Namun sebelum dilaksanakan proses implementasi terlebih dahulu dilaksankaan proses uji validasi oleh ahli terhadap instrumen HOTS berbasis Two tier diagnostic test sebagaimana pada Gambar 1.

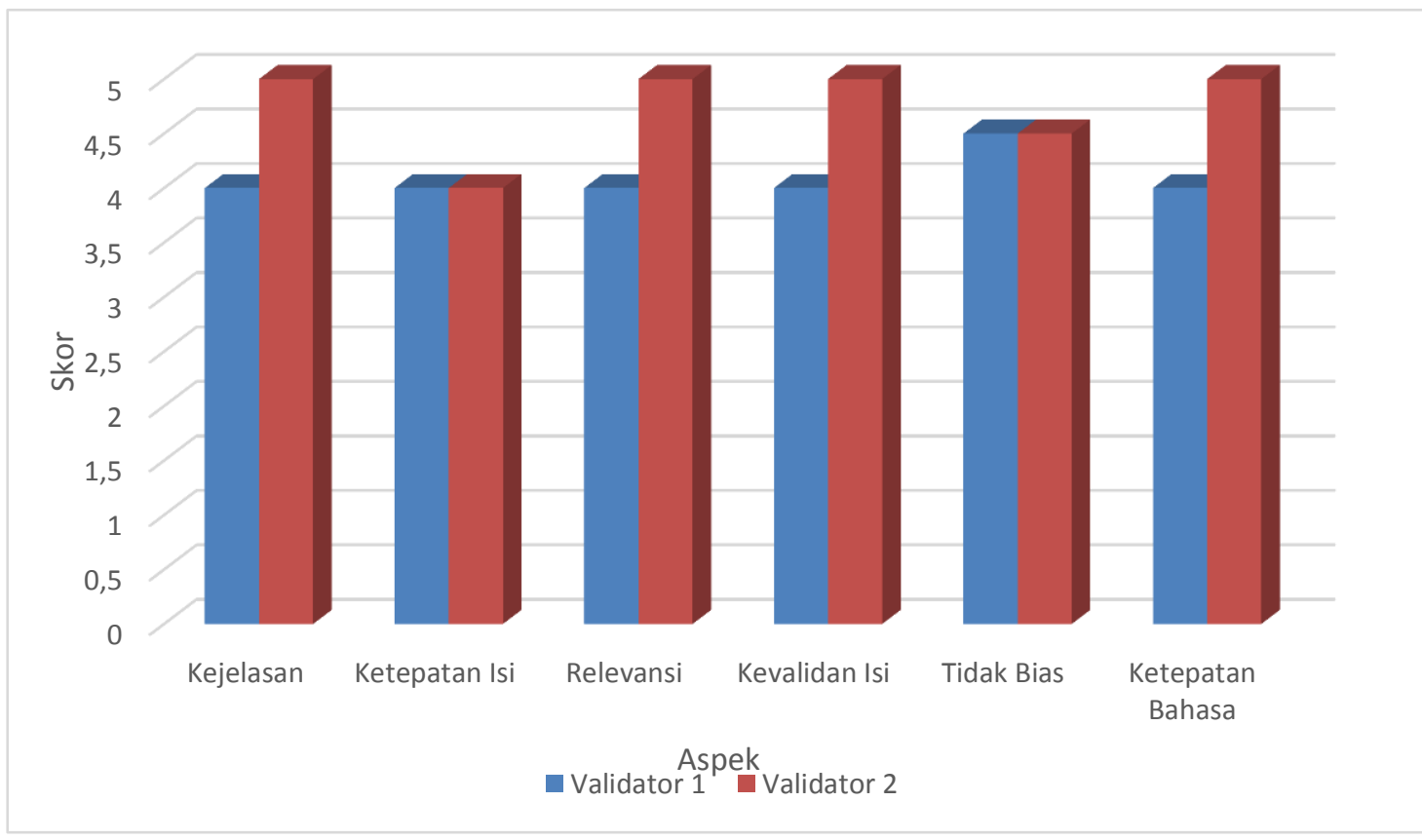

Gambar 1. Hasil Validasi ahli.

Sesuai Gambar 1 memaparkan bahwa instrumen yang telah dirancang berada pada kategori valid dengan ratarata hasil penilaian kedua validator sebesar 4,42. Hal ini menjelaskan bahwa instrumen ini sudah dapat di implementasikan di lapangan.

\section{Uji Normalitas}

Pengujian normalitas data dipergunakan agar dapat menemukan apakah data tersebut berdistribusi normal atau tidak dengan menggunakan uji Kolmogorov-Smirnov sebagaimana tersaji pada Tabel 3.

Sesuai Tabel 3 hasil uji normalitas diperoleh taraf signifikansi sebesar 0,086, maka dari itu dapat ditarik kesimpulan bahwa data berdistribusi normal karena memenuhi kriteria yaitu taraf signifikan $>0,05$. Sejalan dengan (Nahrisah \& Imelda, 2015) dan (Saerang et al., 2014) yang menjelaskan bahwa metode dalam 
DOI: https://doi.org/10.24127/ajpm.v10i4.4260

menyimpulkan hasil uji tersebut dengan

dan pengujian statistik.

memperhatikan penganalisasian grafik

Tabel 3. Uji Normalitas

\begin{tabular}{llr}
\hline$N$ & & 24 \\
\hline Normal Parameter $^{\mathrm{a}, \mathrm{b}}$ & Mean & 0.0000000 \\
& Std. Deviation & 0.81375465 \\
\hline Uji Statistik & & 0.166 \\
\hline Taraf. Sig. (2-tailed) & & $0.086^{\mathrm{c}}$ \\
\hline a. Uji Distribusi adalah Normal. & \\
b. Jumlah data. & & \\
c. Taraf Signifikansi Lilliefors & & \\
\hline
\end{tabular}

Uji Homogenitas

Pengujian dilaksanakan untuk mengindentifikasi kesamaan atau ketidaksamaan varians data. Pengujian dilaksanakan menggunakan SPSS 25 sebagaimana pada Tabel 4.

Tabel 4. Uji Homogenitas

\begin{tabular}{|c|c|c|c|c|c|}
\hline & m Pengujian & $\begin{array}{l}\text { Statistik } \\
\text { Levene }\end{array}$ & df1 & df 2 & Sig. \\
\hline \multirow{4}{*}{$\begin{array}{l}\text { Hasil } \\
\text { Pengerjaan } \\
\text { Instrumen } \\
\text { HOTS }\end{array}$} & Rata-Rata & 0.586 & 2 & 21 & 0.566 \\
\hline & Median & 0.449 & 2 & 21 & 0.645 \\
\hline & $\begin{array}{l}\text { Median dan dengan df } \\
\text { yang disesuaikan }\end{array}$ & 0.449 & 2 & 16.586 & 0.646 \\
\hline & Rata-rata Pengurangan & 0.572 & 2 & 21 & 0.573 \\
\hline
\end{tabular}

Berdasarkan Tabel 4 uji homogenitas mendapatkan hasil Signifikansi sebesar 0,566, sejalan dengan kaidah penarikan keputusan apabila skor signifikansi $(0,566)>0,05$ sehingga variansi data semester $2,4,6$ memiliki data yang homogen. Sejalan dengan (Anggraeni et al., 2019) \& (Rosdiana et al., 2018) menjelaskan bahwa kriteria data dikatakan homogen apabilla nilai signifikansi lebih tinggi atau $>0,05$.

\section{Uji Hipotesis}

Pencapaian kemampuan berpikir tingkat tinggi mahasiswa semester II, IV dan VI dapat dilihat dari skor pengerjaan instrumen HOTS berbasis two tier diagnostic test yang didapatkan.
Pada Gambar 2 menampilkan tentang hasil kemampuan berpikir yang didapatkan. 
DOI: https://doi.org/10.24127/ajpm.v10i4.4260

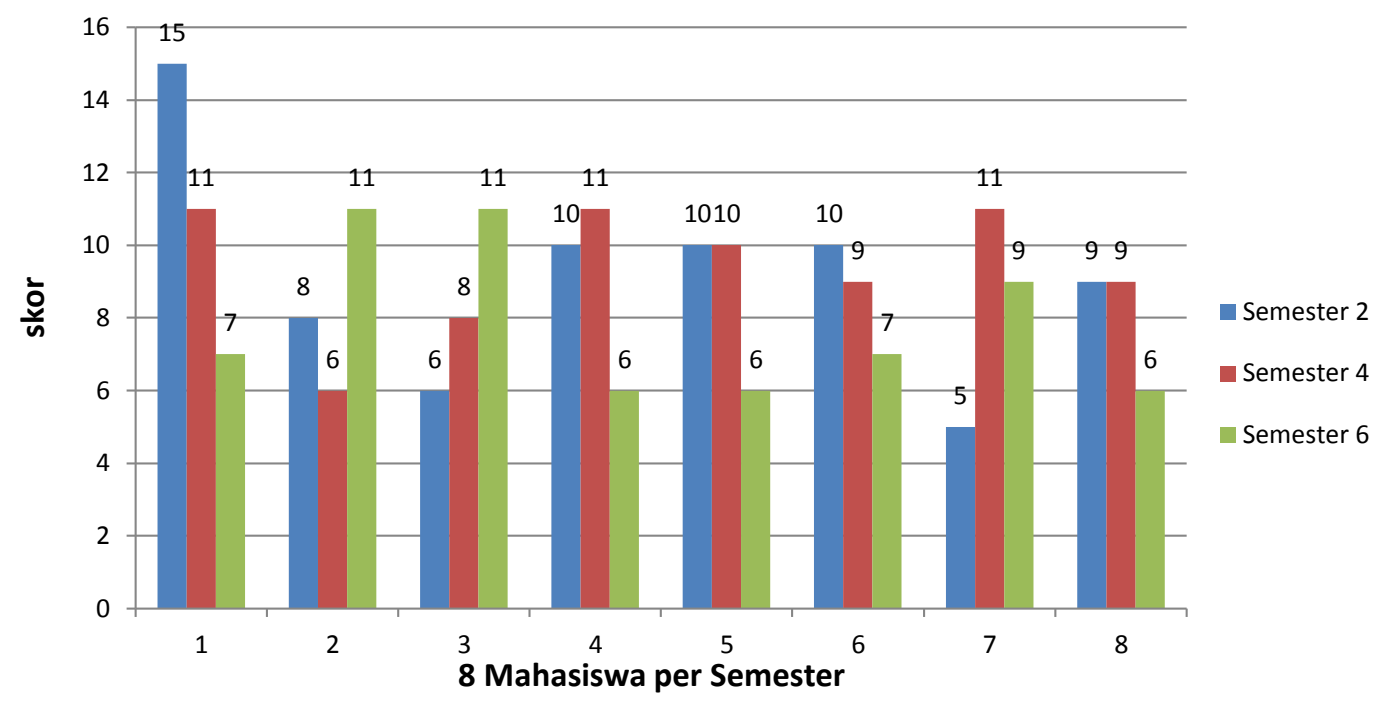

Gambar 2. Skor HOTS berbasis two tier diagnostic tes

Berdasarkan Gambar 2 diperoleh data nilai 8 mahasiswa dari semester II yaitu 15, 8, 6, 10, 10, 10, 5, dan 9. Kemudian nilai 8 mahasiswa dari semester IV yaitu 11, 6, 8, 11, 10, 9, 11, dan 9. Dan nilai 8 mahasiswa dari semester VI yaitu 7, 11, 11, 6, 6, 7, 9, dan 6. Kemudian, skor tertinggi yang didapatkan adalah 15 dan skor terendah 5 dari 24 mahasiswa yang ada pada semester II, IV dan VI. Hal ini terlihat pada hasil uji normalitas dan homogen yang terdistribusi normal dan homogen, sehingga dapat diteruskan pada pengujian selanjutnya sebagaimana pada Tabel 5 dan 6.

Berdasarkan Tabel 5 menunjukkan hasil uji regresi sebesar 0,303. Berdasarkan hipotesis yang telah ditentukan, dimana $\mathrm{H}_{0}$ : Penggunaan instrumen soal Higher Order Thinking Skills berbasis Two Tier Diagnostic Test tidak efektif terhadap kemampuan berpikir tingkat tinggi mahasiswa dan $\mathrm{H}_{1}$ : Penggunaan instrument soal Higher Order Thinking Skills berbasis Two Tier Diagnostic Test efektif terhadap kemampuan berpikir tingkat tinggi mahasiswa. Maka dari hasil analisis uji hipotesis didapatkan $\mathrm{H}_{0}$ diterima dan $\mathrm{H}_{1}$ ditolak dikarenakan skor $t_{\text {hitung }}-1,054<$ $\mathrm{t}_{\text {tabel }}$ dengan taraf Signifikansi 0,303> 0,05 .

Berdasarkan hasil analisis hipotesis diatas, maka ditunjukkan bahwa penggunaan instrumen soal Higher Order Thinking Skills berbasis Two Tier Diagnostic Test tidak efektif dalam mengindentifikasi kemampuan berpikir tingkat tinggi mahasiswa. Akan tetapi, terdapat faktor sehingga penggunaan instrumen soal Higher Order Thinking Skills berbasis Two Tier Diagnostic Test tidak efektif yaitu dikarenakan tidak sesuai dengan interpretasi kemampuuan berpikir tingkat tinggi mahasiswanya, hal ini dapat ditampilkan sesuai dengan hasil uji one way ANOVA pada tabel 6 dengan rata-rata nilai hasil pengerjaan instrumen untuk mahasiswa semester II, IV dan VI adalah rata-rata semester II sebesar 9,1250, kemudian rata-rata semester IV sebesar 9,3750, selanjutnya rata-rata semester VI sebesar 7,8750 dan rata-rata total semester II, IV dan 
VI sebesar 8,7917. Dari data diatas, dapat dilihat tingkat kemampuan berpikir tingkat tinggi mahasiswa semester II, IV dan VI dengan interpretasi semester II berada pada nilai 9,1250 termasuk kategori tingkat interpretasi rendah, kemudian semester
IV dengan nilai 9,3750 termasuk kategori rendah, semester VI dengan nilai 7,8125 termasuk kategori tingkat rendah, dan apabila dilihat dari interpretasi total untuk semester II, IV dan VI yaitu 8,7708 yang memiliki tingkat interpretasi HOTS rendah.

Tabel 5. Uji Regresi

\begin{tabular}{|c|c|c|c|c|c|}
\hline \multicolumn{6}{|c|}{ Koefisien $^{\text {a }}$} \\
\hline \multirow[t]{2}{*}{ Model } & \multicolumn{2}{|c|}{$\begin{array}{l}\text { Koefisien tidak } \\
\text { berstandar }\end{array}$} & \multirow{2}{*}{$\begin{array}{c}\begin{array}{c}\text { Koefisien } \\
\text { Standar }\end{array} \\
\text { Beta }\end{array}$} & \multirow{2}{*}{$\mathrm{t}$} & \multirow{2}{*}{ Sig. } \\
\hline & B & $\begin{array}{l}\text { Std. } \\
\text { error }\end{array}$ & & & \\
\hline \multirow{2}{*}{$\begin{array}{ll}1 & \text { (Tetapan) } \\
& \text { Hasil Pengerjaan } \\
& \text { Instrumen HOTS }\end{array}$} & 2.676 & 0.664 & & 4.032 & 0.001 \\
\hline & -0.077 & 0.073 & -0.219 & $\begin{array}{c}- \\
1.054\end{array}$ & 0.303 \\
\hline
\end{tabular}

a. Dependent Variable: Semester

Tabel 6. Uji Anova

\begin{tabular}{|c|c|c|c|c|c|c|}
\hline & \multirow{2}{*}{$\mathrm{N}$} & \multirow{2}{*}{$\begin{array}{c}\text { Rata- } \\
\text { rata }\end{array}$} & \multirow{2}{*}{$\begin{array}{c}\text { Std. } \\
\text { Deviasi }\end{array}$} & \multirow{2}{*}{$\begin{array}{c}\text { Std. } \\
\text { kesalahan }\end{array}$} & \multicolumn{2}{|c|}{$\begin{array}{c}95 \% \text { Inteval } \\
\text { Kepercayaan Mean }\end{array}$} \\
\hline & & & & & $\begin{array}{c}\text { Batas } \\
\text { Bawah }\end{array}$ & $\begin{array}{l}\text { Batas } \\
\text { Atas }\end{array}$ \\
\hline Semester 2 & 8 & 9.1250 & 3.04432 & 1.07633 & 6.5799 & 11.6701 \\
\hline Semester 4 & 8 & 9.3750 & 1.76777 & 0.62500 & 7.8971 & 10.8529 \\
\hline Semester 6 & 8 & 7.8750 & 2.16712 & 0.76619 & 6.0632 & 9.6868 \\
\hline Total & 24 & 8.7917 & 2.37705 & 0.48521 & 7.7879 & 9.7954 \\
\hline
\end{tabular}

Sesuai dengan pengujian hipotesis yang telah dilaksanakan diperoleh skor $t_{\text {hitung }}-1,054<t_{\text {tabel }}$ dengan taraf signifikansi $0,303>0,05$, hal ini menjelaskan bahwa penggunaan instrumen soal Higher Order Thinking Skills berbasis Two Tier Diagnostic Test tidak efektif terhadap kemampuan berpikir tingkat tinggi mahasiswa. Ketidakefektifan hasil tersebut dikarenakan tingkatan kemampuan mahasiswa masih rendah dalam menganalisis, menguraikan dan menerjemahkan setiap butir soal pada materi yang diberikan. Hal ini dikarenakan para mahasiswa belum diberikan kebiasaan dalam mengasah kemampuannya dalam mengolah setiap informasi yang diberikan melalui kolaborasi pendekatan pembelajaran. Menurut (Kahar, 2017) dan (Kahar, 2018) mengemukakan bahwa penguraian hipotesis dapat menguraikan tingkat pemahaman mahasiswa secara eksplisit sehingga memunculkan pemetaan keberhasilan pembelajaran. Menurut (Widana, 2017) menjelaskan bahwa penerapan HOTS dapat 
memberikan gambaran secara jelas kepada mahasiswa tentang pemahaman pada suatu materi pembelajaran. Akan tetapi adapun faktor sehingga instrument soal Higher Order Thinking Skills berbasis Two Tier Diagnostic Test tidak efektif yaitu dikarenakan kemampuan HOTS mahasiswa di Universitas Muhammadiyah Sorong Prodi Pendidikan Matematika belum mampu untuk menggunakan instrumen soal Higher Order Thinking Skills berbasis Two Tier Diagnostic Test, hal ini dapat dibuktikan dengan hasil interpretasi mahasiswa setelah mengerjakan instrument soal yang telah diujikan menggunakan SPSS 25 dengan Uji one way ANOVA pada tabel 5 dengan hasil rata-rata nilai pengerjaan instrumen untuk mahasiswa semester II, IV dan VI adalah rata-rata semester II sebesar 9,1250, kemudian rata-rata semester IV sebesar 9,3750, selanjutnya rata-rata semester VI sebesar 7,8750 dan rata-rata total semester II, IV dan VI sebesar 8,7917.

Jika dilihat dari data pada tabel 6 yang dikaitkan dengan penilaian yang ada pada tabel 2 maka ditemukan bahwa rata-rata kemampuan mahasiswa dalam mencerna setiap persoalan yang diberikan berada pada rata-rata 8,7708 yang memiliki tingkat interpretasi HOTS Rendah. Hal menjelaskan bahwa mahasiswa masih memerlukan pembelajaran yang lebih bervariasi lagi yang menekankan pada aspek penguasaan keterampilan dan kemampuan menelaah informasi dengan mengupayakan sistem pembelajaran yang terintegrasi. Sejalan dengan (Ramadhan et al., 2018; Saraswati \& Agustika, 2020) yang menjelaskan bahwa instrumen yang digunakan layak dan reliabel, namun pada hasil olah data pada penelitian ini juga diperoleh intrepretasi skor HOTS masih rendah di dalam menyelesaikan persoalan yang diberikan. Selain itu, Menurut (Pratama \& Retnawati, 2018) mengemukakan bahwa penilaian HOTS dapat memberikan secara spesifik dapat menguraikan secara jelas pemahaman mahasiswa, disisi lain sejalan dengan (Putri, Sri Diana, Djamas, 2017) menjelaskan aspek yang bisa mendorong peningkatan kemampuan berpikir mahasiswa merupakan dengan penerapan perangkat pembelajaran yang maksimal sehingga memudahkan dalam pemahaman materi belajar. Adapun kelebihan dari penelitian ini adalah mampu mendorong mahasiswa dalam merangsang kemampuan berpikirnya sehingga dapat mempermudah dalam memahami setiap materi yang diberikan saat proses pembelajaran, selain itu penggunaan instumen yang terintegrasi dengan HOTS ini mampu memetakan kemampuan mahasiswa pada setiap informasi yang diberikan. Disisi lain, kekurangan yang ditemukan saat penelitian mencakup mahasiswa masih membutuhkan waktu lebih eksplisit dalam mengeksplorasi setiap materi yang diberikan agar mampu menemukan solusi pada setiap permasalahan yang diberikan. Kemudian implikasi yang ditimbulkan dari penggunaan instrumen HOTS menggunakan Two Tier Diagnostic Test, dimana mahasiswa mampu secara komprehensif menemukan formulasi dalam memahami materi dan persamaan yang dalam setiap soal yang diberikan, sehingga mendorong mahasiswa mampu dalam mengerjakan setiap persoalan dan permasalahan yang diberikan. 


\section{KESIMPULAN DAN SARAN}

Sesuai dengan hasil dan pembahasan yang ditelah dijabarkan diatas, maka diperoleh kesimpulan bahwa penggunaan instrumen HOTS berbasis Two tier diagnostic test belum mampu meningkatkan kemampuan berpikir tingkat tinggi mahasiswa, hal ini dikarenakan rata-rata hasil interpretasi pengerjaan soal HOTS masih tergolong rendah.

Saran dari penelitian yang dilaksanakan perlu adanya pengembangan instrumen yang mengarah pada pengkajian dan menganalisis proses penilaian secara spesifik. Hal ini diharapkan mampu memberikan pemahaman dan penilaian yang lebih jelas kepada mahasiswa.

\section{DAFTAR PUSTAKA}

Anggraeni, R., Sulton, S., \& Sulthoni, S. (2019). Pengaruh Multimedia Tutorial Terhadap Hasil Belajar Bahasa Indonesia. Jurnal Kajian Teknologi Pendidikan, 2(2), 96101.

https://doi.org/10.17977/um038v2i 22019p096

Dewanti, S. S. (2011). Mengembangkan

Kemampuan Berpikir Kritis

Mahasiswa Bangsa Melalui

Pemecahan Masalah. Prosiding

Seminar Nasional Matematika, 2937.

Facione, P. a. (2011). Critical Thinking:

What It Is and Why It Counts.

Insight Assessment, ISBN 13: 978-

1-891557-07-1., $1-28$.

https://www.insightassessment.co $\mathrm{m} / \mathrm{CT}$-Resources/Teaching-Forand-About-Critical-

Thinking/Critical-Thinking-WhatIt-Is-and-Why-It-Counts/CriticalThinking-What-It-Is-and-Why-ItCounts-PDF
Heong, Y. M., Othman, W. B., Yunos, J. B. M., Kiong, T. T., Hassan, R. Bin, \& Mohamad, M. M. B. (2011). The Level of Marzano Higher Order Thinking Skillsamong Technical Education Students. International Journal of Social Science and Humanity, 1(2), 121-125.

https://doi.org/10.7763/ijssh.2011. v1.20

Kahar, M S; (2017). Analisis Kemampuan Berpikir Matematis Siswa SMA kota Sorong terhadap Butir Soal dengan Graded Response Model. Tadris: Jurnal Keguruan Dan Ilmu Tarbiyah, 2(1), 11. https://doi.org/10.24042/tadris.v2i1 .1389

Kahar, M S. (2018). Motivation Analysis Learning in The Implementation of Physics Practicum. Jurnal Ilmiah Pendidikan MIPA, 8(1), 1-6. http://journal.lppmunindra.ac.id/in dex.php/Formatif/article/view/228 $5 / 1858$

Kurniasih, A. W. (2012). Scaffolding sebagai Alternatif Upaya Meningkatkan Kemampuan Berpikir Kritis Matematika. Kreano, Jurnal Matematika Kreatif-Inovatif, 3(2), 113-124. https://doi.org/10.15294/kreano.v3i 2.2871

Mahmuzah, R. (2015). Peningkatan Kemampuan Berpikir Kritis Matematis Siswa SMP Melalui Pendekatan Problem Posing. Jurnal Peluang, 4(1).

Mukhlisa, N., Pasinggi, Y. S., \& Tuken, R. (2020). PKM Pelatihan Pengembangan Two - Tier Diagnostic Test Disertai Certainty Of Response Index ( CRI ) Bagi Guru SDN Wilayah II Kecamatan 
DOI: https://doi.org/10.24127/ajpm.v10i4.4260

Tanete Rilau Kabupaten Barru. 402-408.

Nahrisah, E., \& Imelda, S. (2015). Dimensi Organizational

Citizenship Behavior (OCB) dalam Kinerja Organisasi. Jurnal Ilmiah Kohesi, 3(3).

Nuryanti, L., Zubaidah, S., \& Diantoro, M. (2018). Analisis Kemampuan Berpikir Kritis Siswa SMP. Jurnal Pendidikan: Teori, Penelitian, Dan Pengembangan2, 3(2), 155-158.

Pratama, G. S., \& Retnawati, H. (2018). Urgency of higher order thinking skills (\{HOTS $\}$ ) content analysis in mathematics textbook. In Journal of Physics: Conference Series, 1097(1).

Putri, Sri Diana, Djamas, D. (2017). Pengembangan Perangkat Pembelajaran Fisika Berbasis Keterampilan Berpikir Kritis dalam Problem-Based Learning. Jurnal Ilmiah Pendidikan Fisika Al-Biruni, $\quad 6(1), \quad 125$. https://doi.org/10.24042/jpifalbirun i.v6i1.648

Ramadhan, G., Dwijananti, P., \& Wahyuni, S. (2018). Analisis Kemampuan Berpikir Tingkat Tinggi (High Order Thinking Skills) Menggunakan Instrumen Two Tier Multiple Choice Materi Konsep dan Fenomena Kuantum Siswa SMA di Kabupaten Cilacap. Unnes Physics Education Journal, 85.

Rohmah, Z., \& Handhika, J. (2018). Two-Tier Test Diagnostik sebagai identifikasi miskonsepsi tahap awal materi kinematika gerak lurus siswa Kelas X MIA MAN 1 Kota Madiun. In Quantum: Seminar
Nasional Fisika, Dan Pendidikan Fisika, 25, 552-556.

Rosdiana, Tanah Boleng, D., \& Susilo. (2018). Two-Tier Test Diagnostik sebagai identifikasi miskonsepsi tahap awal materi kinematika gerak lurus siswa Kelas X MIA MAN 1 Kota Madiun. Seminar Nasional Quantum, 552-553.

Saerang, I., Tommy, P., \& Christiano, M. (2014). Analisis Terhadap Rasio-rasio Keuangan Untuk Mengukur Profitabilitas Pada Bank-bank Swasta Yang Go Public Di Bursa Efek Indonesia. Jurnal Riset Ekonomi, Manajemen, Bisnis Dan Akuntansi, 2(4), 817-830. https://doi.org/10.35794/emba.v2i4 .6490

Saraswati, P. M. S., \& Agustika, G. N. S. (2020). Kemampuan Berpikir Tingkat Tinggi Dalam Menyelesaikan Soal HOTS Mata Pelajaran Matematika. Jurnal Ilmiah Sekolah Dasar, 4(2), 257. https://doi.org/10.23887/jisd.v4i2.2 5336

Suwarto. (2013). Pengembangan Tes Diagnostik Dalam Pembelajaran. Pustaka Belajar.

Wardani, R., Yamtinah, S., \& Mulyani, B. (2015). Instrumen Penilaian Two-Tier Test Aspek Pengetahuan Untuk Mengukur Keterampilan Proses Sains (Kps) Pada Pembelajaran Kimia Untuk Siswa Sma/Ma Kelas X. Jurnal Pendidikan Kimia Universitas Sebelas Maret, 4(4), 156-162.

Widana, I. W. (2017). Higher order thinking skills assessment (\{HOTS $\})$. JISAE, 3(1), 32-44. 